\title{
PENGEMBANGAN MEDIA PEMBELAJARAN ELMOBAR (ELEKTRONIK MODUL ALJABAR) UNTUK SISWA KELAS VII SMP
}

\author{
Putri Kartikasari ${ }^{1}$, Novisita Ratu ${ }^{2}$ \\ ${ }^{1,2}$ Program Studi Pendidikan Matematika FKIP Universitas Kristen Satya Wacana Salatiga \\ 202016008@student.uksw.edu
}

\begin{abstract}
Algebra is an abstract material that is considered difficult by most VII grade students of junior high school. These difficulties can be overcome by the innovation of new learning tools. In this case the development of ELMOBAR learning media (Electronic Module Algebra) is carried out through the 5 stages of ADDIE. The results of this study indicate that ELMOBAR meets the validity index $>61 \%$. The percentage of results of material validation was $81,25 \%$ with a good category and media validation was $96 \%$ with a very good category. The product trial results show that the ELMOBAR learning media has fulfilled the index of practicality of the media for use by $81 \%$ with a good category or feasible to use. In addition, ELMBOBAR learning media can also improve student's learning outcomes in Algebra material. This is shown from the results of the effectiveness test through the pretest and post test results obtained that an increase in student's learning by 0,37 with a category of moderate improvement.
\end{abstract}

Keywords : Electronic Modules, Development, Algebra

\begin{abstract}
Abstrak
Aljabar merupakan salah satu materi yang sifatnya abstrak yang dianggap sulit oleh kebanyakan siswa kelas VII SMP. Kesulitan tersebut dapat teratasi dengan adanya inovasi sarana pembelajaran yang baru. Dalam hal ini dilakukanlah pengembangan media pembelajaran ELMOBAR (Elektronik Modul Aljabar) dengan melalui 5 tahapan ADDIE. Hasil penelitian ini menunjukkan bahwa ELMOBAR memenuhi indeks kevalidan $>61 \%$. Persentase hasil validasi materi sebesar $81,25 \%$ dengan kategori baik dan validasi media sebesar $96 \%$ dengan kategori sangat baik. Hasil uji coba produk menunjukkan bahwa media pembelajaran ELMOBAR telah memenuhi indeks kepraktisan media untuk digunakan sebesar $81 \%$ dengan kategori baik atau layak untuk digunakan. Selain itu media pembelajaran ELMBOBAR juga dapat meningkatkan hasil belajar siswa pada materi Aljabar. Hal ini ditunjukkan dari hasil uji keefektifan melalui pretest dan posttes memperoleh hasil bahwa terjadi peningkatan belajar siswa sebesar 0,37 dengan kategori peningkatan sedang.
\end{abstract}

Kata Kunci : Modul Elektronik, Pengembangan, Aljabar

\section{PENDAHULUAN}

Aljabar merupakan materi matematika yang sifatnya abstrak. Terdapat banyak konsep yang harus dikuasai oleh siswa dengan penalaran. Berdasarkan kurikulum 2013 cakupan isi materi aljabar mendapat porsi yang cukup besar. Hal ini mengindikasikan bahwa aljabar menjadi salah satu komponen penting pada kurikulum matematika di SMP. Sehingga pembelajaran yang kurang memadai dapat menyebabkan ketidak berhasilan pembelajaran matematika di sekolah. Terkait dengan hal tersebut melihat hasil nilai UN siswa jenjang SMP se kota salatiga khususnya pada materi aljabar terlihat masih sangat rendah dibandingkan dengan materi yang lain dengan persentase siswa menjawab soal benar sebesar $41,88 \%$. Hal ini berarti proses belajar mengajar terkait materi aljabar belum dapat mencapai tujuan pembelajaran sesuai yang di inginkan karena memang pada 
Pengembangan Media Pembelajaran Elmobar (Elektronik Modul Aljabar) Untuk Siswa Kelas VII SMP, Putri Kartikasari, Novisita Ratu

kenyataannya siswa menganggap bahwa materi aljabar ini sangat sulit untuk dipelajari dan guru juga kurang memfasilitasi siswa dalam proses pembelajaran yang berlangsung.

Indhaka (2016) berpendapat bahwa dalam pembelajaran yang biasanya dilakukan guru dirasa kurang maksimal karena kurangnya kemampuan guru dalam menyampaikan materi pembelajaran, kurang luasnya pengetahuan guru dan kebanyakan guru hanya menggunakan metode ceramah dimana siswa akan merasa bosan selama pembelajaran berlangsung selain itu juga karena kurangnya dukungan fasilitas pembelajaran seperti media/alat peraga sebagai sarana pendukung yang digunakan untuk pembelajaran matematika terkait materi aljabar sehingga menyebabkan siswa jadi kurang tertarik untuk belajar.

Salah satu cara agar siswa tertarik untuk belajar adalah dengan menciptakan suasana belajar yang menyenangkan misalnya belajar dengan dengan menggunakan media pembelajaran. Sadiman (1986) berpendapat bahwa menurutnya media pembelajaran merupakan sarana yang paling tepat untuk membantu proses pembelajaran karena dengan menggunakan media pembelajaran dapat merangsang fikiran siswa dan mampu menarik perhatian serta minat siswa untuk belajar. Proses belajar mengajar akan berjalan efektif dan efisien dengan bantuan media pembelajaran (Satrianawati,2018). Selain itu, belajar dengan menggunakan media pembelajaran yang dibuat dengan menyesesuaikan tingkat pemahaman siswa dan tingkat kecepatan dalam berpikir siswa dapat membuat siswa menjadi lebih aktif sehingga siswa akan dapat lebih dengan mudah menerima pembelajaran matematika yang memuat banyak konsep-konsep dan juga rumus didalamnya bukan lagi dengan kebiasaan mengahafal saja tetapi dapat menemukannya sendiri. Media pembelajaran yang tepat dan sesuai dengan tingkat pemahaman dan kecepatan berpikir siswa adalah media pembelajaran berupa modul (Saputra, Falahudin, dan Testiana, 2016).

Modul adalah bahan ajar yang dibuat sistematis dan dibuat semenarik mungkin agar siswa tertarik untuk belajar secara mandiri dan melalui modul siswa dapat mengukur kemampuannya sendiri terkait materi yang sedang dipelajari (Mardiah,2018). Modul pembelajaran juga sebagai satuan program belajar mengajar terkecil yang diajarkan oleh siswa kepada dirinya sendiri (self instructional) (Mayer, 2009:472). Namun Seiring dengan perkembangan teknologi di era disrupsi 4.0 pada saat ini mengalami masa transisi disemua bidang khususnya dalam bidang pendidikan yang mana terjadi banyak perubahan seperti beralihnya bahan ajar tercetak ke bahan ajar digital yaitu adanya buku elektronik atau e-book. Sebuah buku cetak dalam versi elektronik yang dapat digunakan pada gadget/smartphone.

Gadget/Smartphone merupakan alat elektronik yang mudah dibawa dan dapat digunakan kapan saja sebagai alat komunikasi dan juga sebagai sumber semua informasi yang orang butuhkan, bukan hanya orangtua saja yang menggunakan gadget tetapi juga kalangan pelajar Hal ini didukung oleh hasil penelitian yang dilakukan Nurmalasari (2018) dan Muflih (2017). Adiwijaya (2015) menyatakan bahwa dalam pembelajaran saat ini siswa perlu suatu pembelajaran yang sifatnya visual dimana dengan adanya media pembelajaran hanya buku-buku saja tetapi bisa dengan suatu inovasi 
yang baru yang lebih menarik lagi dari buku. Melihat hal tersebut maka dilakukanlah penelitian pengembangan media pembelajaran ELMOBAR (Elektronik Modul Aljabar).

ELMOBAR (Elektronik Modul Aljabar) merupakan media pembelejaran berupa modul elektronik yang dapat digunakan pada gadget/samartphone. ELMOBAR dirancang untuk digunakan secara mandiri, mudah digunakan dimana saja dan kapan saja. ELMOBAR ini diciptakan dengan tujuan memperoleh media pembelajaran yang valid, praktis, dan efektif ketika digunakan untuk pembelajaran matematika serta dengan adanya media pembelajaran ini dapat meningkatkan hasil belajar siswa pada pembelajaran matematika khususnya pada materi aljabar.

\section{METODE}

Jenis penelitian ini adalah penelitian pengembangan atau Reserch and Development (R\&D) dengan melalui 5 tahapan pengembangan yaitu tahapan ADDIE yang terdiri dari Analysis, Design, Development, Implementation, dan Evaluation. Penelitian pengembangan ini dilakukan untuk menghasilkan suatu produk yang telah diuji keefektifannya (Slameto, 2012). Modul Elektronik Aljabar merupakan produk yang dihasilkan dalam penelitian ini yang diujicobakan kepada 29 siswa kelas VII SMP. Desain untuk metode penelitian dengan tahapan ADDIE dapat dilihat pada Gambar 1.

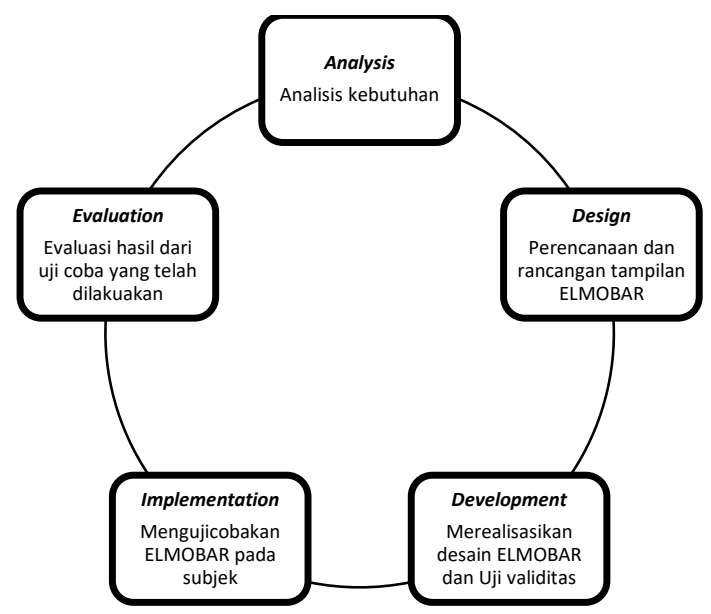

Gambar 1. Desain Metode Penelitian

Teknik pengumpulan data yang dilakukan oleh peneliti adalah dengan menggunakan lembar validasi, lembar kepraktisan media, da gn lembar keefktifan media. Lembar validasi berguna untuk mengetahui kevalidan media baik dari segi materi maupun dari segi media dengan perolehan skor sebesar $61 \%$ yang termasuk dalam kategori baik. Lembar kepraktisan media berupa lembar pernyataan dan lembar pendapat siswa berguna untuk mengukur apakah media pembelajaran ELMOBAR praktis untuk digunakan siswa. Dinyatakan praktis apabila mendapat skor sebesar $61 \%$ dengan kategori baik. Lembar keefektifan media berupa lembar pretest dan posttest berguna untuk mengetahui dan mengukur apakah media pembelajaran ELMOBAR efektif untuk digunakan, 
Pengembangan Media Pembelajaran Elmobar (Elektronik Modul Aljabar) Untuk Siswa Kelas VII SMP, Putri Kartikasari, Novisita Ratu

dinyatakan efektif apabila terjadi peningkatan hasil belajar siswa yang diuji dengan menggunakan rumus $N$-Gain yang dihitung dengan bantuan Microsoft Office Excel.

\section{HASIL}

Pengembangan media pembelajaran ELMOBAR (Elektronik Modul Aljabar) dilakukan dengan melalui 5 tahapan ADDIE yang terdiri dari Analysis, Design, Development, Implementation, dan Evaluation. Tahapan ADDIE dilakukan secara berurutan guna menciptakan media pembelajaran ELMOBAR yang valid, praktis, dan efektif. Berikut uraian dari 5 tahapan ADDIE yang sudah dilakukan :

\section{Analyze (Tahap Analisis)}

Hasil dari tahap analisis adalah dibutuhkannya suatu modul elektronik aljabar atau ELMOBAR yang dapat mendukung pembelajaran siswa sesuai dengan kurikulum 2013 dimana siswa dapat termotivasi untuk belajar secara mandiri dalam memahami konsep-konsep yang ada pada materi aljabar khususnya unsur-unsur bentuk aljabar dan operasi hitung aljabar meliputi penjumlahan, pengurangan, perkalian, perpangkatan, dan pembagian aljabar. Selain dapat memotivasi siswa untuk belajar secara mandiri siswa juga dapat berperan aktif dalam mencapai tujuan belajarnya.

\section{Design (Desain)}

Tahap selanjutnya yaitu tahapan desain. Tahap desain ini dilakukan dengan membuat desain modul elektronik aljabar untuk siswa kelas VII SMP. Desain yang dibuat disesuaikan dengan kurikulum 2013 dimana siswa harus berperan aktif dan mampu belajar secara mandiri. Sebelum ketahapan pengembangan terlebih dahulu modul elektronik aljabar ini disusun dan dirancang dengan bantuan Microsoft Office Word yang meliputi rancangan konsep untuk tampilan modul elektronik aljabar dengan dibuat bagan untuk tampilannya yang meliputi tombol-tombol yang nantinya akan dapat diklik yang meliputi tombol pendahuluan, tombol materi, tombol uji pemahaman, tombol profil diri, tombol backsound, dan tombol exit/keluar. Kemudian rancangan selanjutnya yaitu rancangan untuk isian modul elektronik aljabar untuk masing-masing bagian tombol yang ada yang meliputi isi dari pendahuluan didalamnya terdiri dari KI,KD,Pengalaman belajar, peta konsep, tujuan dan manfaat, serta petunjuk belajar. Selanjutnya isian dari materi didalamnya menyajikan pembahasan materi dan soal evaluasi terkait materi aljabar khususnya unsur-unsur bentuk aljabar dan operasi hitung aljabar. Yang terakhir isian untuk uji pemhaman yang berisi soal-soal sebagai bahan evaluasi keseluruhan materi yang telah dipelajari. Tampilan konsep yang telah dibuat dengan bantuan Microsoft Office Word dapat dilihat pada Gambar 2.

\section{Development (Pengembangan)}

Setelah melakukan tahapan desain ELMOBAR kemudian dilakukan tahapan mengembangkan desain atau rancangan yang telah dibuat dengan bantuan Microsoft Office Word ditransformasikan atau diubah dengan mengguanakan aplikasi Adobe Flash CS6 Professional agar menjadi sebuah aplikasi pembelajaran yang dapat digunakan digadget. Terdapat hal mendasar tetapi penting untuk 
diperhatikan yaitu tampilan awal ELMOBAR harus dibuat semanarik mungkin agar siswa tertarik untuk belajar. Tampilan awal ELMOBAR dapat dilihat pada Gambar 3.

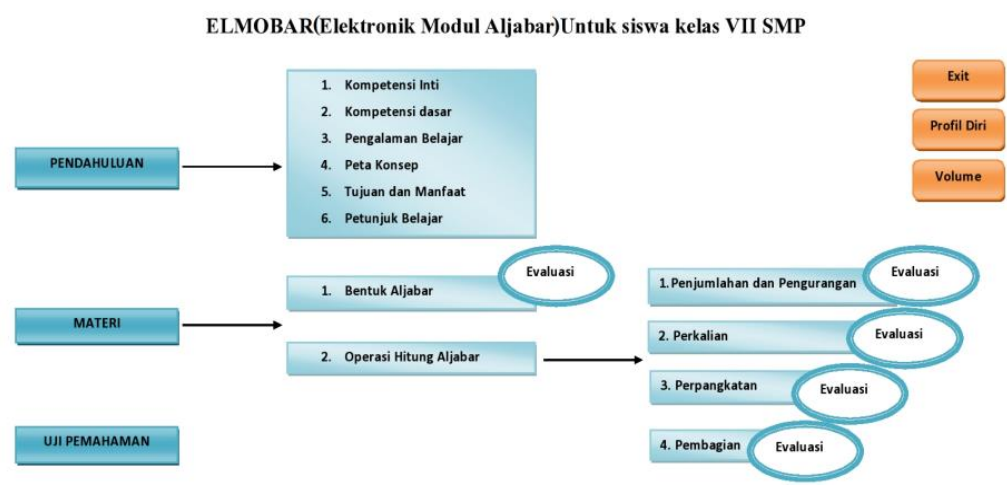

Gambar 2. Konsep ELMOBAR

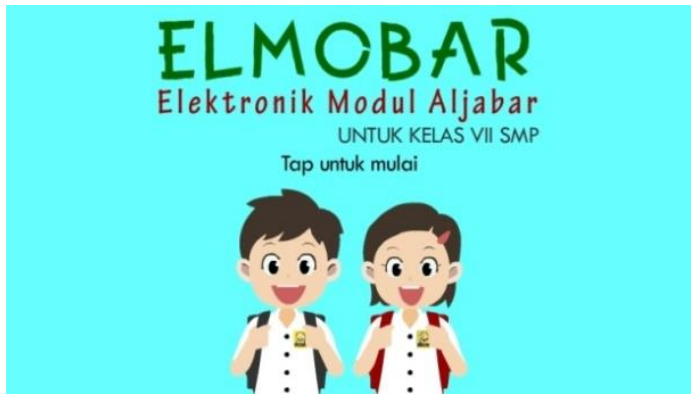

Gambar 3. Tampilan awal ELMOBAR

Setelah tampilan awal ELMOBAR tampilan selanjutnya yaitu tampilan menu ELMOBAR yang terdiri dari tombol-tombol yang dapat diklik meliputi tombol silang berwarna merah merupakan tombol exit/keluar jika ingin keluar dari aplikasi, tombol tanda seru berwarna kuning merupakan tombol profil diri dari pemilik aplikasi, tombol speaker berwarna hijau merupakan tombol backsound untuk menghidupkan atau mematikan musik. Untuk lebih jelasnya dapat dilihat pada gambar 3 berikut.

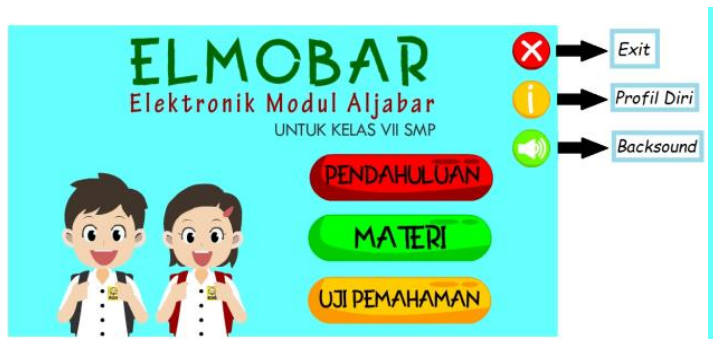

Gambar 3. Tampilan menu awal ELMOBAR

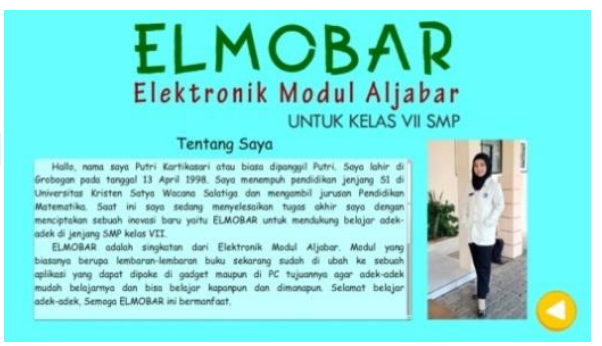

Gambar 4. Tampilan profil diri

Selain tombol-tombol yang telah disebutkan masih terdapat beberapa tombol lagi yaitu tombol pendahuluan, tombol materi, dan tombol uji pemahaman. Pada tombol pendahuluan ketika diklik didalamnya terdapat beberapa tombol lagi yaitu tombol KI, KD, Pengalaman belajar, Peta konsep, Tujuan dan manfaat, serta petunjuk belajar yang dapat dilihat pada Gambar 5 berikut. 


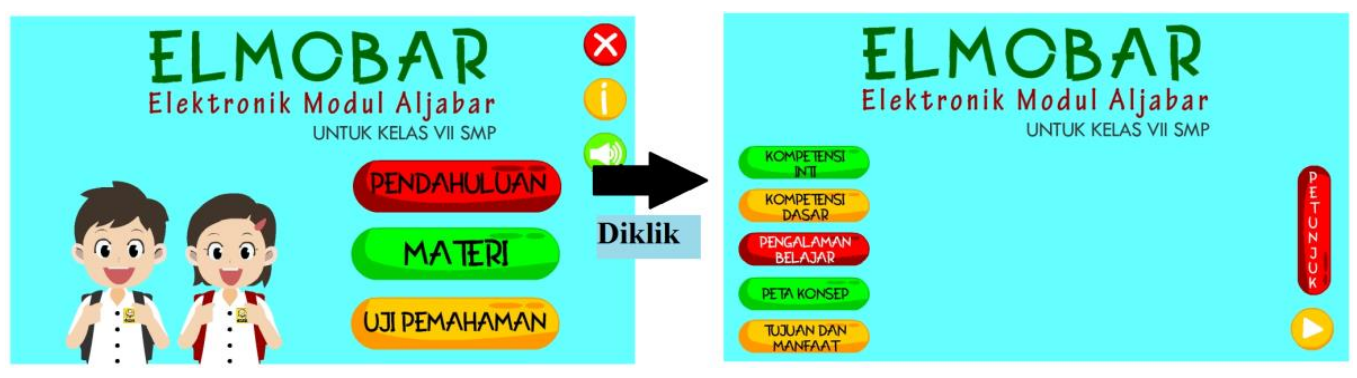

Gambar 5. Tampilan pendahuluan

Berikutnya ada tombol materi dimana pada tombol materi ini juga sama terdapat beberapa tombol lagi yang terdiri dari tombol pembahasan materi dan tombol evaluasi untuk masing-masing sub bab materi yang dibahas meliputi sub bab materi unsur-unsur bentuk aljabar dan operasi hitung aljabar. Pada tombol sub bab materi operasi hitung aljabar ketika diklik tombolnya akan masuk pada tampilan sub bab materi yang terdiri dari penjumlahan dan pengurangan, perkalian, perpangkatan, dan pembagian yang masing-masing pembahasan disertai dengan tombol berwarna merah isinya adalah evaluasi untuk masing-masing sub bab materi yang telah dipelajari. Tampilan pada tombol materi dapat dilihat pada gambar 6 berikut.
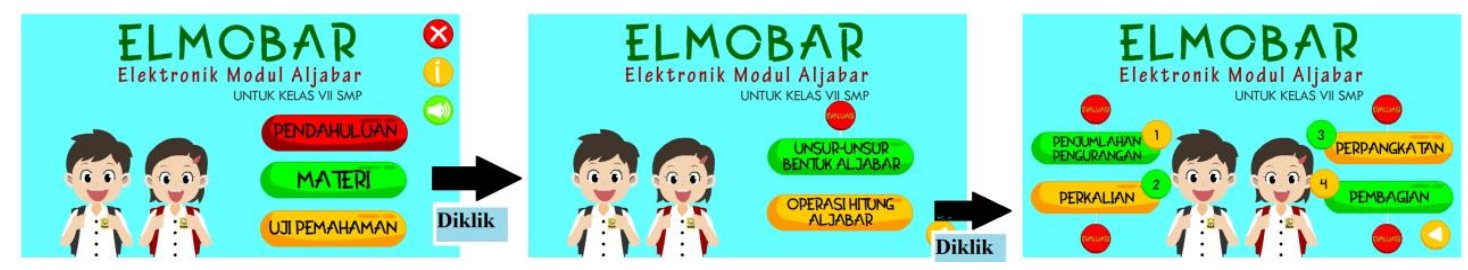

Gambar 6. Tampilan materi

Pada Gambar 6 diatas yang menunjukkan ketika tombol materi diklik akan masuk pada tampilan sub bab materi yang dilengkapi dengan soal-soal evaluasi yang akan ditampilkan ketika tombol berwarna merah diklik. Tampilan untuk salah satu pembahasan materi beserta evaluasinya dapat dilihat pada Gambar 7 dan Gambar 8 berikut.
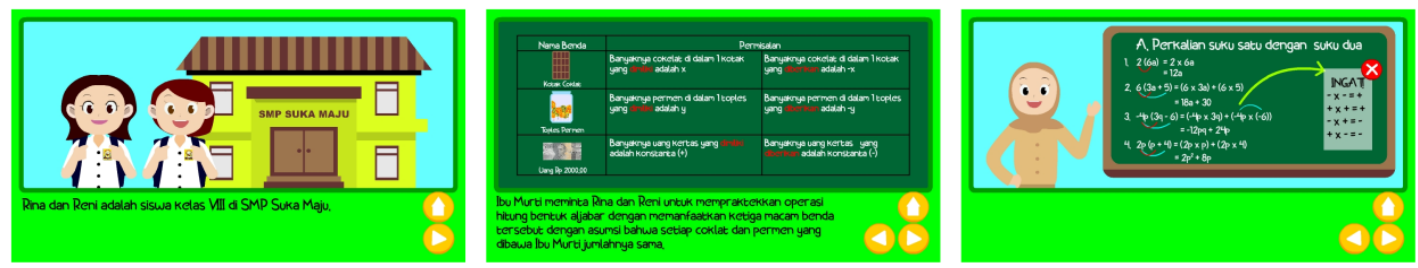

Gambar 7. Tampilan pembahasan materi

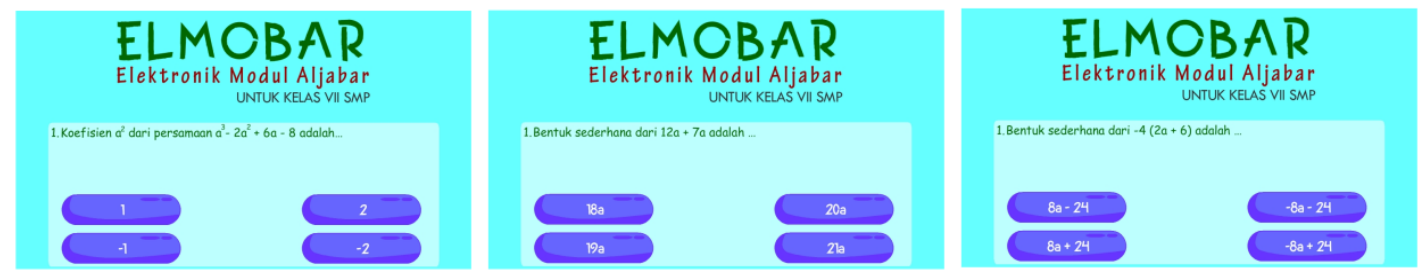

Gambar 8. Tampilan evaluasi 
Tombol terakhir adalah tombol uji pemahaman ketika tombolnya diklik akan masuk pada halaman uji pemahaman yang terdapat sebuah tombol play berwarna orange ketika tombol tersebut diklik akan masuk pada soal-soal evaluasi untuk keseluruhan sub bab materi yang telah dipelajari. Tampilan uji pemahaman dapat dilihat pada Gambar 9 berikut.

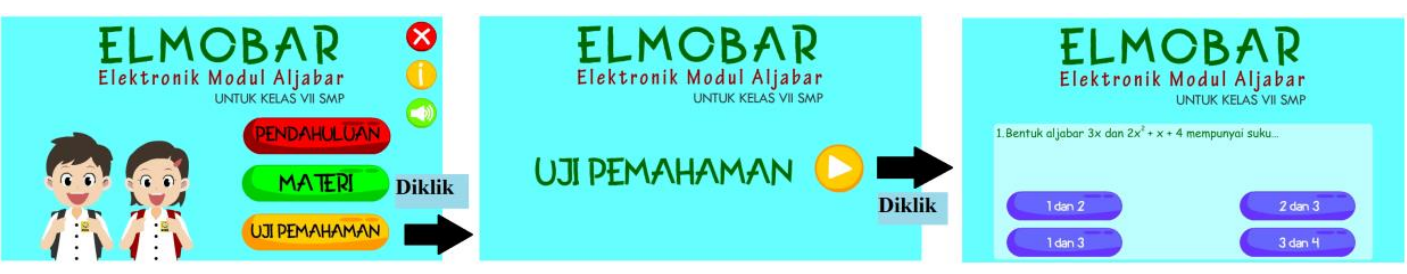

Gambar 9. Tampilan uji pemahaman

Pada saat menjawab soal yang ada pada masing-masing bagian baik untuk bagian evaluasi masing-masing sub bab materi maupun untuk bagian uji pemahaman akan muncul tampilan untuk setiap soal setelah memilih option yang ada akan muncul 3 bintang yang mana ketika 3 bintang itu muncul berwarna kuning maka jawaban benar jika muncul 3 bintang tidak menyala maka jawaban salah. Diakhir ketika selesai menjawab seluruh soal akan tampil jumlah jawaban yang berhasil dijawab sebanyak berapa soal untuk membantu pengguna ELMOBAR agar dapat mengetetahui letak kesalahannya dan dapat kembali diulangi lagi sampai mendapatkan jawaban yang benar dan tepat. Untuk lebih jelasnya lihat Gambar 10 berikut.
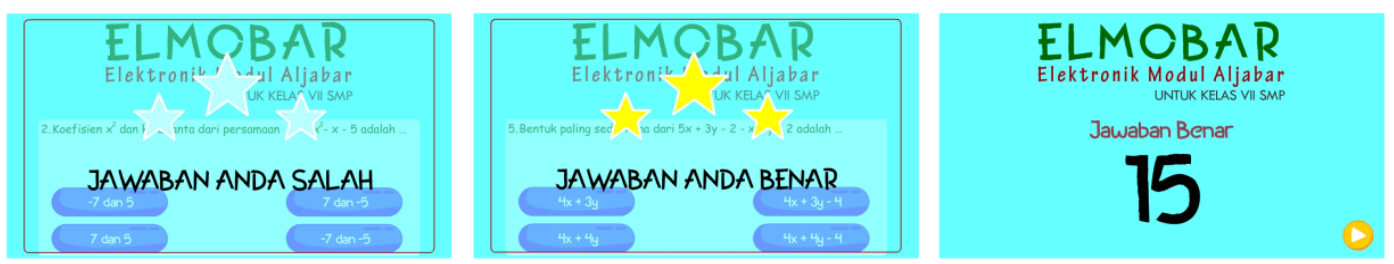

Gambar 10. Tampilan jawaban soal

Sebelum di lanjutkan ke tahapan selanjutnya yaitu tahap implementation atau tahap uji coba lapangan, media pembelajaran ELMOBAR ini terlebih dahulu diujikan kepada validator ahli materi dan ahli media untuk mengetahui kelayakan atau kevalidan media pembelajaran sebelum diujicobakan ke lapangan. Validator ahli materi untuk media ELMOBAR ini adalah salah satu dosen program studi pendidikan matematika. Penilaian yang diberikan dapat dilihat pada tabel 1 berikut.

\section{Tabel 1.}

Hasil validasi ahli materi

\begin{tabular}{|l|c|c|}
\hline \multicolumn{1}{|c|}{ Indikator } & Skor & Kategori \\
\hline Aspek Kurikulum Sesuai \\
\hline $\begin{array}{l}\text { Materi relevan dengan kompetensi yang harus dikuasai } \\
\text { peserta didik }\end{array}$ & 3 & Sesuai \\
\hline $\begin{array}{l}\text { Contoh-contoh penjelasan relevan dengan kompetensi } \\
\text { yang harus dikuasai }\end{array}$ & 3 & Sesuai \\
\hline $\begin{array}{l}\text { Kedalaman uraian materi sesuai dengan tingkat } \\
\text { perkembangan peserta didik }\end{array}$ & 3 & \\
\hline \multicolumn{2}{|c|}{ Aspek Penyajian Materi } \\
\hline
\end{tabular}


Pengembangan Media Pembelajaran Elmobar (Elektronik Modul Aljabar) Untuk Siswa Kelas VII SMP, Putri Kartikasari, Novisita Ratu

\begin{tabular}{|c|c|c|}
\hline Menyajikan kompetensi yang harus dikuasai peserta didik & 4 & $\begin{array}{l}\text { Sangat } \\
\text { sesuai }\end{array}$ \\
\hline Menyajikan informasi pendukung & 4 & $\begin{array}{l}\text { Sangat } \\
\text { sesuai }\end{array}$ \\
\hline \multicolumn{3}{|l|}{ Aspek Evaluasi } \\
\hline $\begin{array}{l}\text { Kesesuaian soal evaluasi dengan kompetensi dasar, tujuan, } \\
\text { dan indikator }\end{array}$ & 4 & $\begin{array}{l}\text { Sangat } \\
\text { sesuai }\end{array}$ \\
\hline Tingkat kesulitan soal uji pemahaman & 3 & Sesuai \\
\hline Variasi soal & 3 & Sesuai \\
\hline Sistematika secara keseluruhan & 3 & Sesuai \\
\hline \multicolumn{3}{|l|}{ Aspek Bahasa } \\
\hline Penggunaan bahasa baku & 3 & Sesuai \\
\hline Penggunaan kalimat yang jelas, tepat serta interaktif & 3 & Sesuai \\
\hline Penyajian soal & 3 & Sesuai \\
\hline Persentase skor kevalidan & $\mathbf{8 1 , 2 5 \%}$ & VALID \\
\hline
\end{tabular}

Berdasarkan Tabel 1, diperoleh total skor sebesar 39 dengan persentase 81,25\%. Skor tersebut termasuk dalam kriteria sangat baik atau sangat layak untuk digunakan. Sehingga media pembelajaran ELMOBAR dinyatakan valid dari segi materi.

Validator selanjutnya adalah salah satu dosen dari pendidikan fisika sebagai validator ahli media pembelejaran ELMOBAR. Penilaian yang diberikan dapat dilihat pada tabel 4.2 berikut.

Tabel 2.

Hasil Validasi Ahli Media

\begin{tabular}{|c|c|c|}
\hline Indikator & Skor & Kategori \\
\hline \multicolumn{3}{|l|}{$\begin{array}{ll} & \text { Aspek Efisiensi } \\
\end{array}$} \\
\hline Alur kerja program media mudah dipahami & 4 & Sangat sesuai \\
\hline Media mudah digunakan dalam pengoperasiannya & 4 & Sangat sesuai \\
\hline Informasi dalam program media mudah dipahami & 3 & Sesuai \\
\hline Dukungan media bagi kemandirian belajar siswa & 4 & Sangat sesuai \\
\hline \multicolumn{3}{|l|}{ Aspek Tampilan } \\
\hline Desainnya menarik & 4 & Sangat sesuai \\
\hline Komposisi warna dalam program media & 4 & Sangat sesuai \\
\hline Pemilihan font dan ukuran huruf sesuai & 4 & Sangat sesuai \\
\hline Kejelasan teks dalam program media interaktif & 4 & Sangat sesuai \\
\hline Peletakan menu-menu dalam program media & 4 & Sangat sesuai \\
\hline \multicolumn{3}{|c|}{ Aspek Komponen multimedia } \\
\hline Kualitas gambar yang digunakan & 4 & Sangat sesuai \\
\hline Ketepatan animasi yang digunakan & 3 & Sesuai \\
\hline Kualitas audio yang digunakan & 4 & Sangat sesuai \\
\hline Persentase skor kevalidan & $96 \%$ & VALID \\
\hline
\end{tabular}

Berdasarkan Tabel 2, diperoleh total skor sebesar 50 dari skor ideal 52 dengan persentase 96\%. Skor tersebut termasuk dalam kriteria sangat baik atau sangat layak untuik di gunakan. Sehingga media pembelajaran ELMOBAR dinyatakan valid dari segi media.

Dari hasil penilaian yang diperoleh pada tabel 4.1 dan tabel 4.2 menunjukkan bahwa media pembelajaran ELMOBAR (Elektronik Modul Aljabar) telah memenuhi indikator kevalidan baik dari segi materi maupun dari segi media. Sehingga dapat disimpulkan bahwa media membelajaran ELMOBAR (Elektronik Modul Aljabar) untuk siswa SMP valid dan layak untuk digunakan. 


\section{Implementation (Implementasi)}

Tahapan ini merupakan tahapan akhir yaitu menguji cobakan media pembelajaran dilapangan. Media pembelajaran ELMOBAR ini diuji cobakan terhadap 29 siswa kelas 7i di SMP Negeri 3 Salatiga. Media pembelajaran ELMOBAR ini diujicobakan dengan cara siswa di berikan pretest, posttest,dan angket respon siswa untuk mengetahui apakah media pembelajaran ELMOBAR ini praktis dan efektif serta dapat meningkatkan hasil belajar siswa. Pretest terdiri dari 10 soal terkait dengan materi aljabar yang diberikan diawal sebelum siswa diminta untuk belajar secara mandiri dengan menggunakan aplikasi ELMOBAR tujuannya untuk mengetahui pemahaman siswa terkait materi aljabar yang sudah mereka dapatkan pada semester sebelumnya. Setelah diberikan pretest barulah siswa dibagikan aplikasi ELMOBAR dengan membawa gadget masing-masing. Sebelum siswa di minta untuk belajar secara mandiri siswa diberi arahan oleh peneliti tentang cara penggunaan ELMOBAR. Siswa harus mengulangi bagian-bagian sub bab materi yang dirasa masih kurang bisa dipahami dan juga diharuskan untuk menyelesaikan soal-soal evaluasi dengan jawaban yang benar. Setelah 2 hari siswa diminta untuk belajar secara mandiri siswa diberikan posttest yang terdiri dari 10 soal dengan bobot soal yang sama dengan soal pretest. Hasil dari pretest dan posttest di gunakan sebagai pembanding sebelum dan sesudah siswa menggunakan aplikasi ELMOBAR dan untuk melihat apakah terjadi peningkatan hasil belajar siswa. Angket respon siswa diberikan diakhir sesudah diberikan posttest guna untuk mengetahui kepraktisan media pembelajaran ELMOBAR. Tahapan implementasi ini dilakukan selama kurang lebih 2 minggu dimulai dari tanggal 19 Februari-29 Februari 2020. Berikut hasil dokumentasi selama pengambilan data yang dilakukan oleh peneliti.

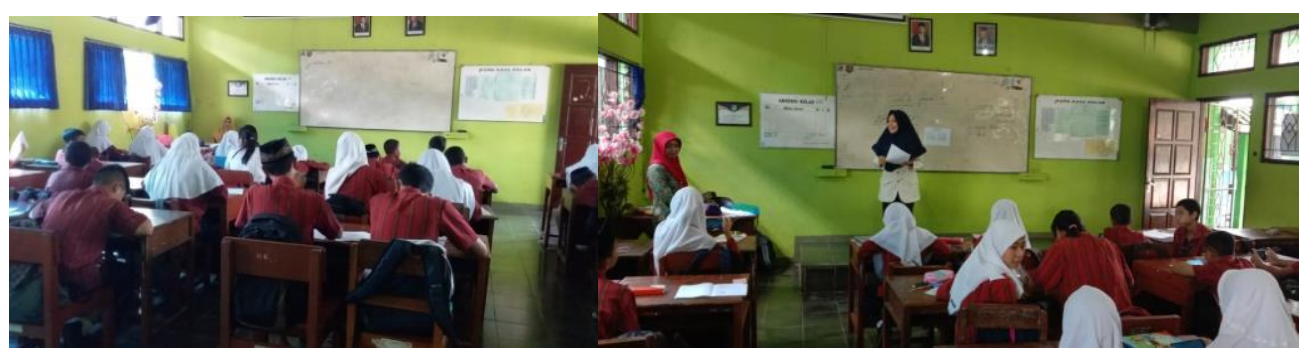

Gambar 11. Observasi kelas

Gambar 12. Pelaksanaan Pretest

( Rabu, 19 Februari 2020)

(Rabu, 26 Februari 2020)

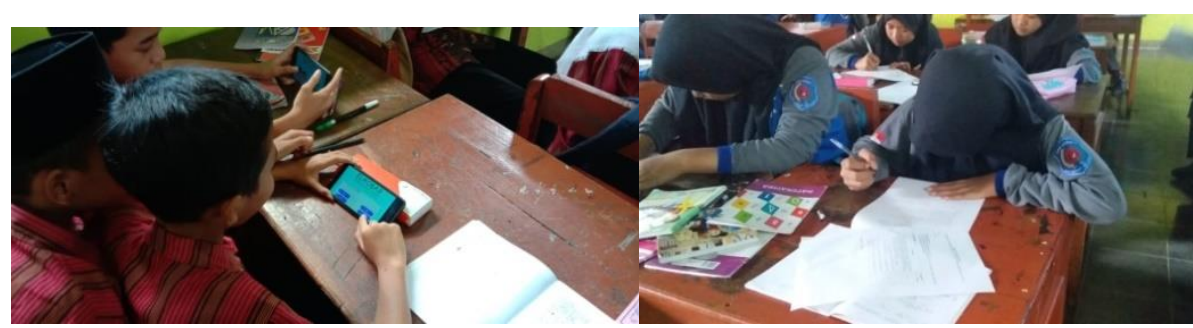

Gambar 13. Penggunaan ELMOBAR

(Rabu, 26 Februari 2020)
Gambar 14. Pelaksanaan posttest

(Sabtu, 29 Februari 2020) 


\section{Evaluation (Evaluasi)}

Pada tahap evaluasi ini peneliti telah memberikan pretest dan posttest kepada subjek yang kemudian hasil dari keduanya menjadi pembanding apakan terjadi peningkata hasil belajar pada siswa sebelum dan sesudah belajar secara mandiri menggunakan aplikasi ELMOBAR. Hasil yang diperoleh dapat dilihat pada Tabel 3 dan perhitungan data dengan bantuan Microsoft Office Excel menggunakan rumus $N$-Gain sebagai berikut.

\section{Tabel 3.}

Hasil pretest dan posttest

\begin{tabular}{|l|l|l|l|l|}
\hline & \multicolumn{2}{|l|}{ Pretest } & Posttest \\
\hline Kelas & Total Skor & Rata-rata & Total Skor & Rata-rata \\
\hline VII I & 464 & 16 & 1367 & 47,13 \\
\hline
\end{tabular}

$\mathrm{N}_{\text {Gain }}=\frac{\text { Skor posttest }- \text { Skor pretest }}{\text { Skor maksimum }- \text { Skor pretest }}$

$\mathrm{N}_{\text {Gain }}=\frac{1367-464}{2900-464}$

$\mathrm{N}_{\text {Gain }}=0,37$

Berdasarkan tabel 3 dan hasil perhitungan dengan menggunakan rumus $N$-Gain diperoleh hasil bahwa terjadi peningkatan hasil belajar siswa kelas 7i sebesar 0,37 dan termasuk dalam kategori peningkatan sedang. Sehingga dapat disimpulkan bahwa dengan penggunaan media pembelajaran ELMOBAR efektif karena dapat meningkatkan hasil belajar siswa terkait dengan materi unsure-unsur bentuk aljabar dan operasi hitung aljabar.

Setelah peneliti meminta subjek untuk belajar secara mandiri dengan menggunakan ELMOBAR, peneliti memberikan angket respon siswa untuk mengetahui kepraktisan ELMOBAR. hasil yang didapat dapat dilihat pada tabel 4 berikut.

\section{Tabel 4.}

Hasil angket respon siswa

\begin{tabular}{|c|c|c|c|c|c|c|c|}
\hline Subjek & P1 & P2 & P3 & P4 & P5 & P6 & P7 \\
\hline 1 & 1 & 1 & 0 & 0 & 1 & 0 & 1 \\
\hline 2 & 1 & 1 & 1 & 1 & 1 & 1 & 1 \\
\hline 3 & 1 & 1 & 1 & 1 & 1 & 1 & 1 \\
\hline 4 & 1 & 1 & 1 & 1 & 1 & 1 & 1 \\
\hline 5 & 1 & 0 & 1 & 1 & 1 & 1 & 1 \\
\hline 6 & 1 & 0 & 1 & 1 & 1 & 1 & 1 \\
\hline 7 & 1 & 1 & 0 & 1 & 1 & 0 & 1 \\
\hline 8 & 1 & 1 & 0 & 1 & 1 & 1 & 1 \\
\hline 9 & 1 & 0 & 1 & 1 & 1 & 0 & 1 \\
\hline 10 & 1 & 1 & 0 & 0 & 1 & 1 & 1 \\
\hline 11 & 1 & 0 & 1 & 1 & 1 & 1 & 1 \\
\hline 12 & 1 & 1 & 1 & 1 & 1 & 0 & 1 \\
\hline
\end{tabular}




\begin{tabular}{|l|l|l|l|l|l|l|l|}
\hline 13 & 1 & 1 & 1 & 1 & 1 & 1 & 1 \\
\hline 14 & 1 & 1 & 0 & 1 & 1 & 1 & 1 \\
\hline 15 & 1 & 1 & 1 & 0 & 1 & 0 & 1 \\
\hline 16 & 1 & 1 & 0 & 1 & 1 & 0 & 1 \\
\hline 17 & 1 & 1 & 1 & 1 & 1 & 1 & 1 \\
\hline 18 & 0 & 0 & 1 & 1 & 0 & 1 & 0 \\
\hline 19 & 1 & 1 & 1 & 1 & 1 & 1 & 1 \\
\hline 20 & 1 & 1 & 0 & 1 & 1 & 0 & 1 \\
\hline 21 & 1 & 1 & 1 & 0 & 0 & 0 & 0 \\
\hline 22 & 1 & 1 & 1 & 1 & 1 & 0 & 1 \\
\hline 23 & 1 & 1 & 1 & 1 & 1 & 1 & 1 \\
\hline 24 & 1 & 1 & 0 & 1 & 1 & 0 & 1 \\
\hline 25 & 1 & 1 & 1 & 0 & 0 & 0 & 0 \\
\hline 26 & 1 & 1 & 1 & 1 & 1 & 0 & 1 \\
\hline 27 & 1 & 0 & 1 & 0 & 0 & 1 & 1 \\
\hline 28 & 1 & 1 & 1 & 1 & 1 & 0 & 0 \\
\hline 29 & 1 & 1 & 1 & 1 & 1 & 1 & 1 \\
\hline
\end{tabular}

$\mathrm{P}=\frac{\sum \mathrm{N}}{\sum \mathrm{N}_{\mathrm{i}}} \times 100$

$\mathrm{P}=\frac{163}{203} \times 100$

$\mathrm{P}=0,8029 \times 100$

$\mathrm{P}=80,29 \%$

Berdasarkan Tabel 4 dan juga hasil perhitungan dengan menggunakan skala Guttman diperoleh hasil skor sebesar 163 jawaban "YA" dari skor ideal 203 dengan persentase 80,29\%. Skor tersebut termasuk dalam kriteria baik dan praktis untuk digunakan. Berdasarkan hasil data yang diperoleh dan telah dianalisis penelitian pengembangan media pembelajaran ELMOBAR matematika terkait dengan materi unsur-unsur bentuk aljabar dan operasi hitung aljabar telah dinyatakan valid, praktis, dan efektif serta dapat meningkatkan hasil belajar siswa pada materi aljabar khususnya dalam materi unsur-unsur bentuk aljabar dan operasi hitung aljabar. Hasil penelitian tersebut juga serupa dengan hasil penelitian yang dilakukan oleh Hayat, Nuim, \& Fitriyani, Harina (2019), Farisyi, A (2018), Zakiyah, H., Purnomo, Djoko., \& Sugiyanti (2019) yang memperoleh hasil yang sama bahwa elektronik modul valid dan layak digunakan untuk mendukung proses pembelajaran.

\section{KESIMPULAN}

Media pembelajaran ini adalah modul elektronik pada materi aljabar untuk siwa kelas VII SMP yang sudah dinyatakan valid, praktis, dan efektif. Hal ini ditunjukkan dari hasil ketiga uji yaitu uji kevalidan, uji kepraktisan, dan uji keefektifan media pembelajaran ELMOBAR. Hasil yang didapat dari uji kevalidan yaitu telah memenuhi indeks kevalidan $>61 \%$ dengan mendapat persentase sebesar $81,25 \%$ dengan kategori baik untuk segi materi dan persentase sebesar $96 \%$ dengan kategori 
Pengembangan Media Pembelajaran Elmobar (Elektronik Modul Aljabar) Untuk Siswa Kelas VII SMP, Putri Kartikasari, Novisita Ratu

sangat baik untuk segi media. Hasil untuk uji kepraktisan dan uji keefektifan media pembelajaran ELMOBAR didapat dari hasil uji coba produk terhadap subjek penelitian.

Media pembelajaran ELMOBAR dinyatakan praktis setelah diujicobakan pada 29 siswa kelas VII SMP. Hal ini terbukti dari hasil uji kepraktisan melalui angket respon siswa yang mendapat skor sebesar 80,29\% dan lembar pendapat siswa yang menyatakan bahwa media pembelajaran ELMOBAR ini dapat menambah manfaat untuk smartphone siswa, mempermudah siswa dalam belajar karena dapat digunakan dimana saja dan kapan saja. Selain itu, Media pembelajaran ELMOBAR ini juga dinyatakan efektif dan mampu meningkatkan hasil belajar siswa terbukti dari hasil pretest dan posttest siswa dimana terjadi peningkatan hasil belajar siswa setelah penggunaan media pembelajaran ELMOBAR ini sebesar 0,37 yang termasuk dalam kategori peningkatan sedang. Dari hasil ketiga uji coba yang telah dilakukan tersebut dapat di simpulkan bahwa media pembelajaran ELMOBAR ini dinyatakan valid, praktis, efektif serta dapat meningkatkan hasil belajar siswa pada materi aljabar terkait unsur-unsur bentuk aljabar dan operasi hitung aljabar. Sehingga media pembelajaran ELMOBAR ini mampu digunakan siswa untuk belajar secara mandiri dan aktif sesuai kurikulum 2013. Selain itu, peneliti menyarankan untuk media pembelajaran ELMOBAR ini dapat ditingkatkan kembali untuk materi yang lebih lengkapnya lagi dan mungkin dapat dikembangkan lagi untuk materi pembelajaran yang lain.

\section{DAFTAR PUSTAKA}

Indhaka, Willy.(2016). Penerapan Buku Sekolah Elektronik Berbasis Android dalam Materi Ajar Besaran dan Satuan.Didaktitum : Jurnal Penelitian Tindakan Kelas, 17(2), 1-2.

Sadiman, Arief S (dkk). (2008). Media pendidikan : Pengertian,pengembangan, dan pemanfaatannya. Jakarta : PT Raja Grafindo Persada.

Satrianawati. (2018). Media dan Sumber Belajar. Yogyakarta : Group Penerbit CV Budi Utama.

Saputra, R., Falahudin, I., \& Testiana, G. (2016). Pengembangan Bahan Ajar Matematika Berbasis Komputer untuk Siswa Kelas VIII di SMP Negeri 19 Palembang. Jurnal Pendidikan Matematika JPM RAFA, 2(2), 248-268

Mardiah, Siti. (2018). Pengembangan Modul Pembelajaran Matematika Berbasis Etnomatematika Menggunakan Metode Inkuiri. 1(2), 119-126.

Mayer, Richard E. 2009. Multimedia Learning Prinsip-prinsip dan Aplikasi. Yogyakarta : Pustaka Pelajar.

Nurmalasari. (2018). Pengaruh Penggunaan Gadget Terhadap Tingkat Prestasi Siswa SMP N Satu Atap Pakisjaya Karawang. Jurnal Ilmu Pengetahuan dan Teknologi Komputer, 3(2), 111-112. 
Muflih, Muflih. (2017). Penggunaan Smartphone dan Interaksi Sosial pada remaja di SMA Negeri Kalasan Sleman Yogyakarta, Idea Nursing Journal, VIII(1), 11-16.

Adiwijaya, M.(2015). Perancangan Game Edukasi Platform Belajar Matematika Berbasis Android Menggunakan Contruct 2, Transient, 4(1), 129-130.

Slameto. 2012. Penelitian dan Inovasi Pendidikan. Salatiga : Widya Sari Press.

Permendikbud Nomor 35 Tahun 2018, Tentang Kurikulum.

Permendikbud Nomor 37 Tahun 2018, Tentang KI dan KD.

Hayat, Nuim., \& Fitriyani, Harina. (2019). Kvisoft Flipbook Maker Pro : Pengembangan E-Modul Matematika Berorientasi Soal Higher Order Thingking Skill Pada Materi Bentuk Aljabar Untuk Siswa Kelas VII SMP. 5(1), Prosiding Sendika.

Farisyi, Salman A. (2018). Pengembangan Modul Elektronik Berpendekatan Contextual Teaching Learning Pada Pokok Bahasan Aljabar Untuk Siswa Mts [Skripsi]. Lampung (ID) : Universitas Islam Negeri Raden Intan.

Zakiyah, H., Purnomo, Djoko., \& Sugiyanti (2019). Pendekatan E-Modul dengan pendekatan kontekstual pada Materi Bilangan Bulat SMP Kelas VII. 1(9), Imajiner : Jurnal Matematika dan Pendidikan Matematika. Semarang : Universitas PGRI Semarang. 